\title{
Papers
}

Explorations into Children's Literature

\section{Haunted by Humans: Inverting the Reality of the Holocaust in Markus Zusak's The Book Thief}

\author{
Aliona Yarova \\ 'It was awful living in that hell full of angels.' \\ (Marquez 1999, p. 224)
}

\section{Inversion in The Book Thief}

In Gabriel García Márquez's A Very Old Man with Enormous Wings a strange angel-like man appears in the human world. A different kind of other-worldly visitor features in Markus Zusak's The Book Thief. ${ }^{1}$ In this text it is Death who takes a journey into the hellish realms of Nazi Germany to discover the humanity of the humans who were dehumanised in the Holocaust. The Book Thief is the story of a nine-year-old Liesel Meminger who lives in Germany during the escalation of World War II. The novel has several levels of the plot development: Liesel's life during war; her relationships with her foster parents Hans and Rosa, the other residents of their neighbourhood, and a Jewish fist-fighter Max, who avoids deportation by hiding in her home; Liesel's book thievery (as the title suggests) and the power of storytelling. The novel is set in a realistically depicted German town and could belong to the genre of historical realism were it not that Liesel's story is narrated by the other-worldly character: Death. Death is the only unreal character in this otherwise realistic 
novel, and though he does not interact with real human characters, we see all the events through his eyes. This 'magical' narrator unveils a broader history of the war and the Holocaust by questioning: What is real? What is normal? What is humane? The inversion enables Zusak to present horror that would otherwise be too complex to grasp. As Hegerfeldt comments: "The world is an absurd place where [...] anything is more believable than the truth. Magic realist fiction proposes that such a topsy-turvy reality requires a similarly inverted approach' (Hegerfeldt 2005, p. 339).

In order to clarify how inversion works, I focus on four central binarisms evident in Death's narrative: the portrayal of the supernatural as natural; humans as ghosts; real as surreal; and presenting life as death. Although these categories are somewhat over-simplified, I suggest that for the child and young adult reader this inversion creates the image of the war as something completely irrational and abnormal. Although the novel has attracted adult readers, my interest lies in explicating how this narrative strategy increases the potential for younger readers to engage with horrifying material, without assuming that they have prior knowledge of the historical events. Inversion is a writing strategy which seems particularly well suited to reaching a YA readership, encouraging teenagers to read about a topic they might otherwise avoid. The goal of this paper is to clarify how this strategy functions in The Book Thief and the subsequent demands it makes of its readers.

\section{The Challenges of Holocaust Representation}

Since the first decade after the war, magic realism has been widely used as a means to portray World War II and the Holocaust in fiction for adults, manifested in novels such as Günter Grass's The Tin Drum (1959), André Schwarz-Bart's The Last of the Just (1959), Jerzy Kosiński’s The Painted Bird (1965), D. M. Thomas's The White Hotel (1981), David 
Grossman's See Under: Love (1990), and Jonathan Safran Foer's Everything Is Illuminated (2002) to name but a few. In children's and young adult Holocaust fiction, magic is a comparatively recent phenomenon. Extensively discussed novels, including Jane Yolen's Devil's Arithmetic (1990) and Briar Rose (1992), Han Nolan's If I Should Die Before I Wake (1994) and Louise Murphy's The True Story of Hansel and Gretel (2003) are closer to historical realism than to magic realism, although they employ magic elements of time-travel and a fairy-tale.

The illumination of the Holocaust in literature for children must navigate numerous problematic demands including historical accuracy, the issue of language's potential to capture atrocity, the degree of exposure to traumatic truth, the implied reader's responses, or as a metaphor for other historical events. Finally, consideration needs to be given to the optimal literary form which would take account of these demands without simplifying the traumatic subject. Hamida Bosmajian (2002) and Lydia Kokkola (2003) provide detailed and insightful analyses of the representation of the Holocaust in children's literature focusing mainly on realist novels. These scholars deal with the issue of how much to reveal and how much to conceal in Holocaust texts for children and the necessity of maintaining historical accuracy. Similarly, David Russell highlights the didactic purpose of Holocaust fiction for children in his discussion of the ethical and moral obligation to speak the truth to children and suggests that: 'knowledge of the Holocaust forces us all to confront fear, ignorance and hatred' (Russell 1997, p. 278). Exposing children to a traumatic history through literature suggests that the role of literature for children has also undergone a major revaluation. Kenneth Kidd claims that 'the emergence of trauma literature for children is a part of this complex history of childhood's revaluation' as adults no longer shield children from cruel 
realities (Kidd 2005, p. 130). However, identifying appropriate ways in which authors should introduce trauma to the young reader remains contentious. As Winifred Whitehead observes: A small factor in the equation, literature, especially books for young people, can have a part to play either in confirming acceptance of violence as an integral part [...] of modern life or as something we must strive to eradicate. (Whitehead 1991, p. 213)

The Holocaust is apparently the most problematic element in the 'equation' as Whitehead identifies a moral imperative for war literature. This overarching goal acknowledges that historical fiction might not necessarily represent history inadequately, but by encouraging readers' engagement with the plot, enables them to respond empathetically to the traumatic content. However, this balance can be achieved only if children's fiction writers manage to create a balance between historical credibility and a reader-engaging plot: 'the task of the artist is to find a style and a form to present the atmosphere or landscape of atrocity, to make it compelling, to coax the reader into credulity—and ultimately, complicity' (Langer, 1975, p. 22). But how can such a balance be reached if the insight becomes too troubling to be represented for young readers? Kokkola admits that children's literature portraying the Holocaust inevitably forces readers to undergo a certain degree of suffering. Kokkola positions her argument against melancholia as an appropriate response for a reader, by stating that 'melancholia is a pathological state', opposing it to mourning, which is a 'healthy way of coming to terms with the loss' (p. 171). Critics, such as Kokkola, Whitehead and B. J. Epstein and others identify works of Holocaust fiction which are of dubious suitability for child readers, but do not propose a successful alternative.

In his article 'A is for Auschwitz', Kidd discusses time-slip narrative in the above-mentioned historical novels by Yolen and Nolan, arguing that these narratives exemplify 'the 
expectation that young readers must find history personally traumatic in order to know it' (2005, p. 133). Kidd refers to Kate Capshaw Smith's argument that 'faith in the power of travel/ trading narratives stems in part from the success of similar texts about African American historical trauma' (p. 133) where the readers are encouraged to experience the horrors of slavery. Kidd finds such 'a metadiscourse of personal suffering' problematic as it 'can sometimes lead to a denial of history's complexities, which aren't always so easily plotted' (Kidd 2005, p. 134). Another Holocaust narrative focused on the protagonist's personal trauma is Judy Blume's Starring Sally J Freedman as Herself discussed in detail by Anastasia Ulanowicz in her recent book Second Generation Memory and Contemporary Children's Literature (2013). Ulanowicz discusses how Blume depicts the protagonist's literal reincarnation of her family's past by weaving together Hollywood and Holocaust imagery (p. 86): the protagonist uses Hollywood-inspired fantasies to play games of War and Concentration Camp in her attempt to act out and confront her cousin's brutal death in Dachau (p. 77). Acknowledging Kidd's and Ulanowicz's observations, alternatives to realist narrative strategies do not always appear to be effective means of representing the bigger picture of genocide. However, both scholars encourage a reconsideration of the role of children's fiction in representing trauma, and suggest that a metadiscourse of personal suffering may stimulate moral development rather than despair. An effect that is somewhat similar to the Aristotelian concept of catharsis.

The question of how artistic expression could plausibly convey the irrationality of World War II without evoking despair, melancholia and hopelessness, remains open for speculation. Obviously, no matter how problematic the representation of the Holocaust is for children, any new attempt to represent the history of Nazi genocide must prevent the topic from falling into oblivion and stimulate historical awareness and its relation to the present. In her discussion of 
the 'chilling tales of the supernatural' (2013, p. 2), Ulanowicz argues that contemporary children's literature narratives aimed at evoking the ghostly memories of historical trauma are 'preoccupied with much more terrifying and tangibly felt specters' (such as the haunting images of concentration camps and battle-ravaged landscapes) than the monstrous and the uncanny from fantastical and Gothic narratives (2013, p.2). She argues that those haunting images are so horrifying that they 'cannot be explained away by any rationalist discourse' ( $\mathrm{p}$. 2). I agree with Ulanowicz's point and propose that the magic realist technique of inversion used in The Book Thief is an attempt to present the traumatic history to the child reader by transgressing the borders of rationalist discourse.

Anne Hegerfeldt defines magic realism as a new form of mimesis, arguing that reality itself has become more unrealistic and literature recreates the abnormal as a norm. Her example is the ghosts in Toni Morrison's Beloved which are: 'no more incredible than the phenomenon of slavery appears, or ought to appear, from a present day perspective' (Hegerfeldt 2005, p. 321). Similarly, in discussion of the Holocaust - an event which shattered human understanding of the real, probable and believable - genocide finds its reflection in the inverted form of magic realist fiction 'transgressive reality'. As Hegerfeldt suggests: 'Political oppression, religious fundamentalism, censorship, genocide, despotism and corruption $[\ldots]$ these elements are fantastic not in that they are physically impossible unfortunately, they only all too obviously are very possible indeed' (p. 323).

Magical worlds are not necessarily places to escape from reality, as they can be places in which readers reflect on their own reality: 'One must understand the magical realist universe not as a flight from reality but as a flight simulator, an artificial world within the real world, meant to prepare us for a better grasp of it' (Arva 2008, p. 78). Simulation is performed 
through readers' empathy, associations, and the magical symbols which they are invited to decode. Magic realist tropes help readers to recapture the real by creating associations between concepts from their prior experience, which invokes their emotional engagement. Joe Langdon defines such an effect as the 'felt' experience of trauma: 'The deliberately ambiguous nature of magical realist texts means that they can often be read in a multitude of ways, often causing the reader to "lose the plot" and feel or experience, rather than objectively observe or understand, occurring events' (Langdon 2011, p. 9). Magic realist Holocaust literature presupposes a catharsis-like engagement with the subject, possibly with a trauma-amplifying effect. But how is such 'felt' experience achieved? Arva suggests that 'magical realist images attempt to recreate traumatic events by simulating the overwhelming affects that prevented their narrativization in the first place' (2008, p. 61, italics original). The events presented in the hidden form are aimed at the reader's engagement and, when trauma is narrated indirectly, the impact is amplified.

Both Langdon and Arva suggest that magic realism operates on a sensory level. Unlike fantasy, magic realism foregrounds the problem of representing reality, which paradoxically 'simulates the sense or experience of something real' (Langdon 2011, p. 3). For adolescent readers, the advantage of magic realism is that it reduces overt didacticism whilst stimulating reflection, resulting in the 'thoughtful literature of atrocity' suggested by Kidd (p. 144) in which readers are guided to recognise the real in the magic elements as a step towards reconsidering the present. Ultimately, as Lois Zamora and Wendy Faris suggest, 'storytellers may need magic to battle death camps and totalitarian regimes' (1995, p. 164). As already noted, the use of 'magical' storytellers who embody inversion is common in magic realist fiction for adults. Children's literature also uses this strategy: the down-to-earth angel in David Almond's Skellig and comforting and healing monster in Patrick Ness's A Monster 
Calls are just two examples. Similarly, Zusak's Death, traditionally portrayed in literature as macabre, becomes humanised and benevolent in the realm of the Holocaust.

\section{Supernatural as Natural}

If we accept that human figures in the novel are expected to be read as though they resemble 'real' people, then we must also accept that Zusak's Death is supernatural and not real. He is made comprehensible by contrasting him with human characters. Death is a sentimental, humorous, and sympathetic character, despite being a ghostly figure that belongs to the afterlife and spiritual world. Magic realist fiction, as Hegerfeldt observes, 'makes the past present in the shape of ghosts' (2005, p. 235). Zusak's ghostly narrator is omniscient in the sense that he knows what is happening in many places at the same time, and can also be physically present as a spirit. For example, Death narrates Liesel's conversation with a mayor's wife and then takes readers to another place to witness what is happening to Max: 'Now for a change of scenery. [...] How about we forget Molching for a minute or two? [...] We will travel a little, to a secret storage room, and we will see what we see. A GUIDED TOUR OF SUFFERING To your left, perhaps your right, perhaps even straight ahead, you find a small black room. In it sits a Jew' (Zusak 2007, KL 1812-1817, capitals original).

By narrating events that are happening in different places simultaneously, Death seems to be more reliable than an omniscient human narrator, and so may invite greater trust from the reader.

Human narrators prevail in fiction, even in novels containing supernatural characters. In contrast, realist Holocaust fiction usually invites readers to share the perspective of a particular character, or from an omniscient perspective that enables readers to witness the same events from multiple - but always human - perspectives. Human narrators are 
inevitably subjective (we see the events from one point of view) and fragmented (we see only the parts of the events available to the narrator), unlike Zusak's Death who sees history in its totality, without fragmentation or interruption. His ghostly capacity to 'float free in time, not just here and now but then and there, eternal and everywhere' (Zamora and Faris 1995, p. 498) makes him an unrestricted, objective narrator of history. Death links the past and the present by calling 'into question the possibilities of a future based on avoidance of the past' (Weinstock 2004, p. 6). Thus Death performs several roles: he is the bearer of historical memory, a source of unlimited knowledge and an embodiment of the past-made-present.

As the holder of collective memory, Death describes seeing 'an eclipse when a human dies. I've seen millions of them. I've seen more eclipses than I care to remember' (Zusak 2007, KL 170). This capacity to remember everything provides Zusak’s Death with distinct advantages over other omniscient narrators. Ghosts' memories are limited to their mortal lifespan and continue into their afterlife as spirits, whereas Death's memory is everlasting, encompassing all histories and cultures. Once readers accept Death's total omniscience, they realise that his narrative does not allow for hesitation over the narrator's reliability: history as seen through Death's eyes is the absolute truth. Zamora and Faris suggest that 'history itself is a ghost' (1995, p. 503), an idea that is captured in Zusak's portrayal of a phantom of the past which never ceases to haunt the present.

The supernatural narration in The Book Thief may leave readers uncertain about where magic ends and reality begins. Such defamiliarisation, Hegerfeldt suggests, is a key feature of magic realism:

Defamiliarization produced by magic realist fiction is due not only to supernaturalization, as critics suggest, but equally to magic realism's matter-of-fact presentation of the unreal, which engenders a considerable amount of reader 
hesitation. [...] In destabilizing received notions of the real and the fantastic, magic realist fiction reveals the extent to which both categories are matter of social and cultural consensus $[\ldots]$ The world contains things more wonderful, but also vastly more horrific, then the human imagination will allow for. (2005, p. 200)

Death's encounters with humans have a similar effect: humans are uncanny, strange and, thus, unnatural to Death. Readers are also encouraged to take on this perspective, and interpret humans as unnatural, whilst Death is perceived as natural, possessing human-like features: 'Please, trust me. I most definitely can be cheerful. I can be amiable. Agreeable. Affable. And that's only the A's' (Zusak 2007, KL 82-83).

Death is invisible for the human characters who operate in the realist mode; the magical and the real are not juxtaposed, they co-exist. As Teya Rosenberg explains: 'The fantastic suggests natural or supernatural while magic realism suggests natural and supernatural' (Rosenberg 2003, p. 79, emphasis added). In The Book Thief, we can see the latter combination but inverted: Death is seen as a part of reality rather than the uncanny, whereas the human world is seen as unnatural and sinister.

Death's role in the narrative resembles the role of the reader as a ghost, as described by Lynne Pearce: 'As a reader, I am a ghost not only because I return, but because I am returning to a text. As a reader I am a voyeur of action in which I cannot participate or intervene' $(1997$, p. 2). The reader haunts the text without being able to affect the lives of characters. Similarly, Zusak's narrator haunts the human world, but does not influence the development of the plot: he merely observes. Death testifies to the atrocities of the Holocaust through his ability to delineate historical reality on multiple dimensions. By resembling the role of the reader, Death leads without didacticism and, in doing so unveils the bigger picture 
of World War II. History becomes more fully accessible as Death leads the reader into inaccessible places such as gas chambers and hidden basements. The technique of inversion enables readers to access history in its most inaccessible places. Thus, the reader becomes familiar with Death: a natural supernatural story-teller.

The narrator seems 'natural' because he is on the same footing as humans; Death has no control over humans as the power structures are inverted. Normally, the 'Grim Reaper' as the personification of Death is assumed to decide when he will take a human life, but Zusak's figure offers a counter viewpoint claiming that, during the war, humans - not Death himself have the power over life and death. For instance, at the beginning, Death introduces himself with the statement: 'Here is a small fact. You are going to die' (Zusak 2007, KL 80). Later he adds that he does not decide when the person's time comes, it depends 'on a diverse range of variables' (Zusak 2007, KL 88). In granting authority to humans and admitting his own powerlessness, Death highlights human responsibilities for murder: 'I am not violent. I am not malicious. I am a result' (Zusak 2007, KL 119). Death in wartime is not fate: it is a direct consequence of human violence. Death reminds readers that humans could avoid death. He describes how man 'already cheated me in one world war, but would later be put into another [...] where he would somehow manage to avoid me again' (Zusak 2007, KL 401). The fact that a man can "cheat" and "avoid" Death suggests that fate is in human hands; humans are responsible for crimes against humanity. As the novel recalls the innumerable victims of the Holocaust, humans are shown to dehumanise 'others', whereas the humane, albeit ghostly, narrator is perceived as natural. The magic realist technique of inversion removes reader hesitation about the nature of Death-as-narrator making him a super-natural character: a ghost who is as natural as a human, but simultaneously superior to humans. 


\section{Death as Human}

The personification of Death has a long-standing tradition in European literature from oral traditions onwards. Death has been variously envisaged as 'the skeleton with the hourglass', the 'god of sleep', 'the rider on the pale horse', 'the hunter', 'dancer', 'judge', 'grave-digger', 'gardener', 'fisherman', 'fowler with his net' (Guthke 1999, p. 11). Death has been given the face of a 'monster', 'guardian of the gates of Hell', 'the grinning skeleton', 'the sardonic jester' (Neill 1997, p. 5). Despite the multiplicity of Death's faces in literature, they share one inherent feature: the macabre. Death is always ominous, terrifying, 'the threatening Other' (Neill 1997, p. 5). Apparently this characteristic originates from Death's generally infamous anti-humane 'job'. The uniqueness of Death in The Book Thief is that he is presented as a human, and, perhaps, the most 'humane' character in the novel. Death himself admits the peculiarity of being emotional and frequently talks about his heartfelt moments: 'You see? Even death has a heart' (Zusak 2007, KL 3010). A sharp sense of humour, expressed through ironic and skeptical storytelling, creates a sense of the proximity of Death to humans.

In The Book Thief, Death's humour has several functions. The narrator's ironic language predisposes the reader's affinity toward Death, making him likable. However, this characteristic not only serves to shape readers' impressions of Death's humanness, it also amplifies Death's scepticism towards humans. The sinister humour of the narrator is subversive and his ironic comments accentuate the ridiculousness of the war:

They say that war is death's best friend, but I must offer you a different point of view on that one. To me, war is like the new boss who expects the impossible. He stands over your shoulder repeating one thing, incessantly: "Get it done, get it done." So you work harder. You get the job done. The boss, however, does not thank you. He asks for more. (Zusak 2007, KL 3919) 
Karen Coats notes that 'Death's grim humour reflects his idealist stance with regard to people [...] they continually surprise him, prompting a humorous response to the incongruity of what he sees' (Coats, 2011, p. 328). Such incongruity creates dissonance as the human, not magical, world is the source of conflict. Inversion presents Death as more sensible than humans.

Even though Death adopts a god-like position, his human foibles make him approachable: 'I only wear a hooded black robe when it's cold' (Zusak 2007, KL 3892). Interestingly, Death describes his human features in episodes where humans are only souls: 'I blow warm air into my hands, to heat them [souls] up' (Zusak 2007, KL 4484). When Death tries to heat the shivering souls he seems to blow life into the bodiless beings, which makes Death even more physical than humans.

Death's sentimental personality also makes him more human. Eric Tribunella suggests: 'Both protagonist and reader can experience the pain of loss and the pain of reading about a historical atrocity, but also the pleasure of sentimentality' (Tribunella 2010, p. 104). Death is the character that enables readers to feel the "pleasure of sentimentality" as they are invited to observe the events from his unique perspective and share his sentimental feelings. Paradoxically, Death is the only character that is not involved in the atrocities of the war either as a victim, or as an offender. When readers empathise with the victims of the war, they incidentally take a similar position to Death, who is exhausted by the process of collecting their souls: 'I'm tired, I'm so tired' (Zusak 2007, KL 6879). Such 'solidarity' in terms of attitudes to humans between Death and the readers situates this supernatural narrator within the readers' realities: the ghostly figure becomes human. 
Death's sentimentality is exemplified through emotionality. For instance, when Death collects the souls of victims exterminated in the gas chamber: 'I picked up each soul that day as if it were newly born. I even kissed a few weary, poisoned cheeks ... and freed them from their fear' (Zusak 2007, KL 4495). This passage characterises Death not only as human-like but also as liking humans, which contrasts sharply with traditional portrayals. Consequently, Death can reveal the 'inhuman' human nature. Jenni Adams, however, interprets this passage as an example of magic realist 'escape and consolation narrative' which is 'obscuring the event's traumatic historical reality in their presentation of a narrative of escape which seeks to recuperate the atrocities represented' (Adams 2011, p. 154). Even though Death's narrative in this fragment offers a certain degree of reassurance (in terms of stylistic devices) Adams fails to see how presenting Death as a sentient being is a technique aimed at representing the uncanny as natural, to highlight how humans break natural laws during war. When Death is presented as a human, both aggressors and victims appear less humane: the Nazis because of their cruelty, but also the victims of the Holocaust are turned into ghosts.

\section{Humans as Ghosts}

Death perceives humans as 'ghosts'- uncanny, odd and mysterious - when they are alive. Their ability to start wars is something he finds 'strange [...]. Full of blood and violence - but also full of stories that are equally difficult to fathom' (Zusak 2007, KL 2255). Death's interest in humans largely stems from his curiosity about their odd lives, incomprehensible behaviour as well as a fascination with their endurance. For instance, he describes a mother carrying her dead child:

How could that woman walk?

How could she move? That's the sort of thing I'll never know, or comprehend - what humans are capable of. (Zusak 2007, KL 298) 
Death's inability to "know, or comprehend" humans is analogous to humans' fascination with the mysteries of the supernatural world. Human curiosity about the supernatural - typically superior - is inverted in The Book Thief where humans fascinate the other-worldly character. The world of humans for Death is 'other worldly', strange, confusing and yet thrilling: 'It amazes me what humans can do, even when streams are flowing down their faces and they stagger on, coughing and searching, and finding' (Zusak 2007, KL 6831). Death's amazement or puzzlement about humans remains unresolved, as he cannot directly interact with them: he merely observes, rather than participates. He asks: 'How could that woman walk? How could she move?', but receives no answer. Death cannot form a dialogue with humans, and so they remain distant and mysterious, just as the afterlife remains unimaginable for humans. By foregrounding this inversion, readers are expected to reexamine their previous assumptions.

Death sees living humans as phantoms and encourages readers to follow his example. In the episode where Jews are marching through the city on their way to Dachau, Death explains: 'Some people were moving around. The drizzle made them look like ghosts. Not humans, but shapes, moving about' (Zusak 2007, KL 642). The ghostliness of the humans in the scene does not require a supernatural narrator. Their bodiless shapes intermingling with the drizzling rain, metaphorically portray the annihilation of human life during the war. Yet Death consistently views humans as ghosts, which encourages readers to follow suit and regard even robust figures in a ghostly light. Max is described as being 'as close as possible to a noiseless shadow' (Zusak 2007, KL 2962) in the Hubermans' cellar where he spends months hiding to avoid being exterminated. Max exists in between the living and the dead; he is simultaneously a shadow and a human. 
Andrew Bennett and Nicholas Royle describe ghosts' seeming non-human nature as 'paradoxical since they are both fundamental to the human, fundamentally human, and a denial or disturbance of the human, the very being of the inhuman' (Bennett and Royle 1999, p. 132). Inversion stimulates readers to reconsider whether human always means rational and natural; in the context of the Holocaust, this seems unfounded. Acknowledging Bennett and Royle's intricate definition, the presentation of humans as ghosts in this novel serves to show the victims being deprived of their human dignity, whereas Nazi's inhumane cruelty is contrasted with 'humanised' Death. As a result, the reality of the Holocaust - where humans are ghost-like shadows - is portrayed as surreal. This inversion leads to a deeper level of inversion in which the real is perceived as surreal.

\section{Real as Surreal}

Just as in surrealist paintings where incongruous combinations of objects are collected into a single picture, in The Book Thief grotesque fragments of inverted reality comprise the surreal picture of the Holocaust.

Death, to use Gérard Genette's term, is a heterodiegetic narrator, who is 'absent from the story he tells' (1980, p. 244) and yet remains capable of accessing multiple points of view. Death follows Liesel Meminger throughout her life, but he is equally concerned with providing readers with insights into other human lives. First of all, the omnipresent narrator in this novel is physically displaced; as Death levitates above the earth, proffering readers opportunities to observe the events from inaccessible angles. For example, Death provides access to 'a secret storage room' (Zusak 2007, KL 1819) and even enters and survives the gas chambers. When Death descends 'to do his job', i.e. to collect the souls of dying humans, the reader flies alongside him. This creates a curious effect like a camera zooming in and out, thereby allowing readers to focus on a particular city, house, or character and, subsequently, 
when Death distances himself, readers find themselves elevated above the earth. This narrative technique allows the reader to see events that are happening simultaneously, and the sudden shifts in perspective create a surreal picture of the Holocaust. The result is that, the overall absurdity of World War, the whole 'kaleidoscope of realities' (Arva 2008, p. 80) is brought to the reader's attention. This narrative technique is employed to amplify, as Death says, the 'nonsense of war' (Zusak 2007, KL 2270) by presenting it as surreal:

More than a thousand bomber planes flew toward a place known as Köln. For me, the result was five hundred people or thereabouts ... Five hundred souls. I carried them in my fingers, like suitcases. Or I'd throw them over my shoulder. It was only the children I carried in my arms [...]. My arms ached and I couldn't afford to burn my fingers. There was still so much work to be done. (Zusak 2007, KL 4296)

The surrealism is amplified by the incongruous metaphor of souls as suitcases, whereas the reality of this episode may surpass human imagination. This episode is made believable by the details of Death's physical pain: his human struggles render him more credible. Through the juxtaposition of Death's hurting arms (presented as something trivial) and the death of five hundred people (whose souls are carried as suitcases), the inversion of the real and the surreal is achieved. The text invites readers to see the parallels between the surreal elements: by mentally transforming suitcases into people the emotional engagement is achieved.

Death also enables readers to foresee the future of characters through repetitive flashforwards. For instance, Death explains that '[t]he group of Steiners and Liesel walked past some shop windows and the imposing town hall, which in later years would be chopped off at the knees and buried' (Zusak 2007, KL 628). This knowledge of the future creates a sense of tragic premonition. The stylistic peculiarity of the anthropomorphised buildings 
resonates with the impression of an inverted reality. The destruction of the houses is portrayed as a brutal murder ('chopped off at the knees'). The 'murdered' buildings will be leveled to the ground, just as innumerable victims will be wiped from memory.

There are other passages where the inversion of reality, expressed in Death's description of inanimate objects as sentient, causes a dramatising effect as readers are encouraged to empathise with the pain of people through the surreal images of the houses in pain: 'Shaped like a long, broken arm, the road contained several houses with lacerated windows and bruised walls' (Zusak 2007, KL 638). No injured people are described; instead, the street is depicted as a crippled person. Comparing a road with a broken arm stimulates readers to feel the trauma through association with living persons. The magic realist technique of 'literaliz[ing] metaphor' (Hegerfeldt 2005, p. 258) presents 'lacerated windows' and 'bruised walls', suggesting that the whole world is tortured by the war. It is easier for the imagination to accept the destruction of the street than the destruction of human lives. But this illusionary relief is short-lived, as Zusak exposes the metaphor revealing that the street stands for the annihilated humans. Inversion, achieved by conferring human qualities and physical features on objects, helps readers see afresh: what was dead is alive (the accordion, houses), what was alive is dead (humans).

The representation of the real as surreal in this novel is connected to the irrational. The Book Thief matches the criterion suggested by Elizabeth Baer, that in Holocaust fiction evil must be depicted 'as something totally irrational, something that springs inexplicably, full blown, unannounced, into one's life' (Baer 2000, p. 384). The Holocaust springs, full-blown and unannounced into Death's consciousness: he sees 'the world is a factory. The sun stirs it, the humans rule it. And I remain. I carry them away' (Zusak 2007, KL 6878). This thought- 
provoking comparison of the world with a 'factory' recalls the common use of this metaphor in conjunction with the processing of bodies in the extermination camps. The surreality of history portrayed by Death invites readers to engage with events so overwhelmingly intense that their direct and realistic description would not be plausible in YA literature. Zusak's Death offers veiled images; the readers' task is to unveil them:

Within minutes, mounds of concrete and earth were stacked and piled. The streets were ruptured veins. Blood streamed till it was dried on the road, and the bodies were stuck there, like driftwood after the flood. They were glued down, every last one of them. A packet of souls. Was it fate? Misfortune? Is that what glued them down like that? Of course not. Let's not be stupid. It probably had more to do with the hurled bombs, thrown down by humans hiding in the clouds. (Zusak 2007, KL 179, emphasis added)

The metaphoric portrayal of humans as a 'packet of souls glued to the earth' is unnaturally heavy in comparison with stereotypical descriptions of souls as light and floating. The concept of the soul is inverted, not only because it is physical rather than spiritual, but also because of the down-to-earth characteristic of being glued down, suggesting that even souls have been murdered. 'Ruptured veins' metaphorically stand for both the bombed streets and the bleeding people. The emotions directed towards the inanimate street, irrationally provide a platform for emotional engagement with the human victims.

Christine Brooke-Rose considers that in literature containing magic, 'inversion of real/unreal is perfectly logical. If the "real" has come to seem unreal, it is natural to turn to the "unreal" as real: the two oppositions are interrelated' (Brooke-Rose 1981, p. 4). In Zusak's novel, inverted magic realism is employed to convey the most painful episodes in the novel. The inversion of real as surreal emphasises the monstrosity of the experience of death despite the 
apparently neutral tone: 'A train was moving quickly. It was packed with humans. A sixyear-old boy died in the third carriage' (Zusak 2007, KL 220). This matter-of-fact manner, or following Hegerfeldt's terminology, 'rhetoric of banality' (2005, p. 209), appears striking in contrast with the previous sentimental passage. Readers are invited to accept the 'bitter' reality of the event. Short factual sentences are divested of emotion; the horrific becomes routine, almost incidental. As Arva suggests: 'The deceptive simplicity of magical realist images $[\ldots]$ enables readers to see and feel - without necessarily understanding - the indescribable horrors of the past' (Arva 2008, p. 75). The simplicity of language in the excerpt quoted above is striking in its incompatibility with the terrifying image of death trains and serves to amplify the horror of the Holocaust. This stylistic strategy of juxtaposing mood and manner works to invert readers' perception of reality. Readers are exposed to the totally irrational destruction of humans, and only supernatural Death appears to behave reasonably. Eventually, the combination of the inverted roles of natural and supernatural, humans and ghosts, real and surreal results into a believable representation of human life during the Holocaust as death.

\section{Life as Death}

Most tragic moments in The Book Thief highlight the various levels of inversion outlined above. What could be more surreal and phantasmagoric than Death flying in the whirlpool of souls 'released' every minute from the concentration camps?: 'When their bodies had finished scouring for gaps in the door, their souls rose up. Their fingernails had scratched at the wood and in some cases were nailed into it by the sheer force of desperation ... they just kept feeding me. Minute after minute. Shower after shower' (Zusak 2007, KL 3910). What makes this scene striking and convincing at the same time is the inverted play of life and death. Death, both physical and anthropomorphised, is not to be feared; life, instead, is depicted as terrifying. This reversal acknowledges the reality of victims of Nazi atrocity, 
many of whom committed suicide. Zusak positions readers to feel, to use Hegerfeldt's terms, 'a sense of horror [...] more profound than could have been expressed in words' $(2005, \mathrm{p}$.

87). The magic realist representation of trauma is capable of effecting an emotional connection between the reader and the text. There is no direct description of violence; only the repetition of 'minute' and 'shower' reveal the increasing horror, and the use of 'bodies' instead of 'people' implies that life during the Holocaust is worse than death. Similarly, in another passage, the experience of the concentration camps is depicted as surreal:

I'll never forget the first day in Auschwitz ... There were broken bodies and dead, sweet hearts ... Some of them I caught when they were only halfway down. Saved you, I'd think, holding their souls in midair as the rest of their being-their physical shells-plummeted to the earth. All of them were light, like the cases of empty walnuts. Smoky sky in those places. The smell like a stove, but still so cold. I shiver when I remember - as I try to de-realize it. I blow warm air into my hands, to heat them up. But it's hard to keep them warm when the souls still shiver. (Zusak 2007, KL 4481, emphasis added)

This narrative excerpt is dramatised by the representation of humans in the afterlife. We know nothing about their lives, except that their physical bodies are 'broken' and reminiscent of 'empty walnuts' and 'shells', representing the total devastation of their physical being. These people's lives, their experience in Auschwitz, not their afterlives, could have been narrated instead, and might have been more disturbing and realistic. However, the effect of this passage would not have been as strong without the magical realist images of 'shivering souls' and 'cold sky' (see also Arva 2008, p. 71). These descriptions suggest not only the unbearable cold, amplified by the repetition of the word 'shiver', but also the unbearable pain. According to Arva, magic realist narratives, rich in sensory details and conspicuously lacking specific words describing physical violence, rely on metaphors suggesting the pain 
and horror of the real events $(2008$, p. 61). As readers recognise the magic images as real, the emotional intensity forces them to engage with the trauma. Readers cannot help imagining what has not been said: the atrocity that turned millions of people into empty shells and shivering souls.

Looking at these events from Death's perspective, as he flies over the camps gathering souls, allows readers to not only be exposed to a single character's tragedy, but to the tragedy of innumerable other victims. Reality is a nightmare; dying stands for awakening. This is most concrete when suicidal humans call to Death pleading him to take them:

"Have me," they said, and there was no stopping them. They were frightened, no question, but they were not afraid of me. [...] Michael Holtzapfel [...] killed himself for wanting to live. (Zusak 2007, KL 6389, emphasis added)

This excerpt shows that death and life are inverted; life is no longer valued, death instead is what humans seek. Naturalising suicide takes inversion to its extreme: what can be more unnatural, nonhuman than suicide? The phrase 'he killed himself for wanting to live' turns the concept of life inside out, as an utmost effect of magic realist inversion (KL 6389). Indeed, what were the victims of the Holocaust turned into if not bodiless phantoms? What was the life of people in the concentration camps if not death? What kind of picture is the one of this genocide if not surreal?

\section{Concluding remarks: storytelling and memory}

In his article 'Children, War, and the Imaginative Space of Fairy Tales' (2000), Donald Haase explores how fairy tales help children of war interpret their traumatic war experience by identifying war space with the fairy tale landscape: 'Storytelling itself could become a space for refuge - familiarity - linked to protection, security, and the return to meaningful life' (Haase 2000, p. 366). In the same way, Liesel's thievery of the books is her search (as a child of war) for imaginative space and her subconscious emotional survival strategy in 
extreme conditions. Zusak pays tribute to the power of storytelling already by the novel's intertextuality: Max credits the book Mein Kampf with saving his life, Liesel's first stolen book The Grave Digger's Handbook with its trivialised burial procedure helps her to cope with the traumatic memory of her brother's grave. The Book Thief's magical storyteller is Zusak's attempt to help young readers interpret traumatic history of the Holocaust and to pass the memory of the Holocaust to next generations. The defamiliarising techniques of magic realism protect young readers from knowing more than they are capable of processing, but do not allow them to shy away from the truth. In this way, Zusak invites readers who might otherwise avoid reading about the Holocaust to engage with the historical events.

As this article has argued, the specificity of Death's storytelling lies in the reversal of the concepts normal and abnormal, natural and unnatural, life and death. By inverting these somewhat overstated binarisms, Death's narrative invites young readers to discover the meaning of human, normal and humane in the context of the Holocaust. Even though young readers are not supposed to find peace from this discovery, they come to realise that humans, such as Liesel, Hans, Rosa and Max, managed to retain their humanity in the extreme conditions when some humans were turned into ghosts and lived life which was life-in-death. Death's narrative serves also to accentuate the humanity of the sympathetic humans, while also contrasting with the inhumanity of the Nazis. Through Death's storytelling the memories of these humans in war remain alive even after their bodies are deceased.

Ulanowicz uses the photographic ghost image ${ }^{2}$ as a metaphor for second-generation memory 'which involves the merging of images of the past with those of the immediately experienced present - and, not unlike the uncanny photographic print, unsettles conventional notions of space, temporality, and identity' (p. 5). In the inverted reality of The Book Thief all the 
conventions are unsettled: the uncanny ghost photograph 'depicts' human ghosts hovering over the figure of Death. The striking intensity of Death's closing statement embodies the controversy at the heart of the inversion:

\section{A LAST NOTE FROM YOUR NARRATOR}

I am haunted by humans.

(Zusak 2007, KL 6949, capitals original)

The order of things is reversed: the magic world is haunted by humans. The inversion comes full circle: Humans persecute Death, whilst Death cares for humans. The hunter becomes the hunted, the victimiser the victim. Finally, readers are invited to see that this seemingly irrational, surreal picture has led us to reality and truth: it is not Death who is 'haunted by humans', but we humans who are ceaselessly haunted by the memory of our past.

\section{Notes}

1. Markus Zusak is an Australian writer born to Austrian-German immigrant parents. The novel was inspired by the stories told by Zusak's parents who experienced the horrors of the war firsthand in their native countries. In the interview for Chicago Public Library, he says about his parents: 'They gave me the world of this book like a language I didn't know I had. Sure, there's a ratio of probably 90 percent fiction in the finished work, but it's the world and backdrop of the story that they brought to life.'

(http://www.steppenwolf.org/watchlisten/program-articles/article.aspx?id=301).

2. Ghost image is a term used in photography when two images are superimposed upon one another and whose coincidence on photographic paper produces an eerie effect on the viewer (Ulanowicz 2013, p. 5) 


\section{References}

Adams, Jenni (2011) Magic Realism in Holocaust Literature: Troping the Traumatic Real. Basingstoke, Hampshire: Palgrave Macmillan.

Almond, David (1998) Skellig. London: Hodder Children's Books.

Arva, Eugene (2008) 'Writing the Vanishing Real: Hyperreality and Magical Realism.' Journal of Narrative Theory 38(1): 60-85.

Baer, Elizabeth Roberts (2000) ‘A New Algorithm in Evil: Children's Literature in a PostHolocaust World.' The Lion and the Unicorn 24(3): 378-401.

Bennett, Andrew and Royle, Nicholas (1999) Introduction to Literature, Criticism and Theory. $2^{\text {nd }}$ ed. London: Prentice Hall.

Blume, Judy (2014) Starring Sally J. Freedman as Herself. New York: Simon and Schuster.

Bosmajian, Hamida (2002) Sparing the Child: Grief and the Unspeakable in Youth Literature about Nazism and the Holocaust. New York: Routledge.

Brooke-Rose, Christine (1981) Rhetoric of the Unreal: Studies in Narrative and Structure, Especially of the Fantastic. Cambridge: Cambridge University Press.

Coats, Karen (2011) 'Young Adult Literature: Growing Up Theory'. In. S. Wolf, K. Coats, P. Enciso, \& C. Jenkins (eds.) Handbook of Research on Children's and Young Adult Literature. New York: Routledge, pp. 315-329.

Epstein, B. J., Andrews, K., Gray, M., \& Maws, A. (2013). Discussion Forum Inflicting Trauma: The Ethics of Writing and Teaching the Holocaust for Children. Holocaust Studies, 19(1), 101-120.

Foer, Jonathan Safran (2002) Everything Is Illuminated. London: Penguin.

Grass, Gunter (1982) The Tin Drum. Harmondsworth: Penguin. 
Grossman, David (1999) See Under: Love. London: Vintage.

Genette, Gérard (1980) Narrative Discourse. Oxford: Basil Blackwell.

Guthke, Karl (1999) The Gender of Death: A Cultural History in Art and Literature. Cambridge: Cambridge University Press.

Haase, Donald (2000) 'Children, War, and the Imaginative Space of Fairy Tales'. The Lion and the Unicorn 24(3), 360-377.

Hegerfeldt, Anne (2005) Lies that Tell the Truth: Magic Realism Seen through Contemporary Fiction from Britain. Amsterdam, New York: Rodopi.

Kidd, Kenneth (2005). 'A' is for Auschwitz: Psychoanalysis, Trauma Theory, and the Children's Literature of Atrocity'. Children's Literature 33(1), 120-149.

Kokkola, Lydia (2003) Representing the Holocaust in Children's Literature. New York: Routledge.

Kosiński, Jerzy (1996) The Painted Bird. London: Black Swan.

Langdon, Jo (2011) 'Magical Realism and Experiences of Extremity.' Current Narratives 1(3): 14-24.

Langer, Lawrence (1975). The Holocaust and the Literary Imagination. New Haven: Yale University Press.

Marquez, Gabriel Garcia (1999) ‘A Very Old Man with Enormous Wings’. In G.G. Marquez Collected Stories. New York: pp. 224-227.

Morrison, Toni (1997) Beloved. London: Vintage.

Murphy, Louise (2003) The True Story of Hansel and Gretel. London: Penguin. 
Neill, Michael (1997) Issues of Death: Mortality and Identity in English Renaissance Tragedy. Oxford: Clarendon Press.

Ness, Patrick (2011) A Monster Calls. London: Walker.

Nolan, Han (2003) If I Should Die before I Wake. HMH Books for Young Readers.

Pearce, Lynne (1997) Feminism and the Politics of Reading. London and New York: Hodder Headline Group. pp. 1-36.

Rosenberg, Teya (2003) 'The Influence of the Second World War on Magical Realism in British Children's Literature.' Canadian Children's Literature 111-112: 78-89.

Russell, David (1997) 'Reading the Shards and Fragments: Holocaust Literature for Young Readers'. The Lion and the Unicorn 21(2): 267-280.

Schwarz-Bart, Andre (2001) The Last of the Just. London: Vintage.

Thomas, D.M. (1981) The White Hotel. London: Penguin Books.

Tribunella, Eric (2010) Melancholia and Maturation: the Use of Trauma in American Children's Literature. Knoxville: University of Tennessee Press.

Ulanowicz, Anastasia (2013). Second-Generation Memory and Contemporary Children's Literature: Ghost Images. New York: Routledge.

Weinstock, Jefrey (2004) Spectral America: Phantoms and the National Imagination. Madison: University of Wisconsin Press/Popular Press.

Whitehead, Winifred (1991) Old Lies Revisited: Young Readers and the Literature of War and Violence. London: Pluto Press.

Yolen, Jane (1990) The Devil's Arithmetic. London: Puffin Books. 
Yolen, Jane (1992) Briar Rose. New York: T. Doherty Associates.

Zamora, Lois Parkinson and Faris, Wendy (1995) Magical Realism: Theory, History, Community. Durham, N.C.: Duke University Press,

Zusak, Markus (2007) The Book Thief. Knopf Books for Young Readers, Kindle File.

\section{Biographical Note}

Aliona Yarova holds an MA degree in English from Lviv National University, Ukraine and an MPhil degree in Education (specialisation: Critical Approaches to Children's literature) from the University of Cambridge, England. She is currently a $\mathrm{PhD}$ student of the Department of Art, Communication and Education at Luleå University of Technology, Sweden. Her current research interests include magic realism and eco-criticism in children's literature. Her doctoral dissertation preliminary title is 'Narrating Humanity: Children's Literature in Global Citizenship Education'. 